\title{
Cyanobacteria of Surface and Ground Waters in Asir Region with New Records to Kingdom of Saudi Arabia
}

\author{
Zakaria A. Mohamed and Abdulrahman M. Al-Shehri \\ Department of Biological Sciences, Faculty of Science, King Khalid \\ University, Abha, 9004, Saudi Arabia
}

\begin{abstract}
Cyanobacteria were surveyed in six surface water bodies and six ground water wells in Asir region, Southwest of Saudi Arabia between August and December 2003. A total of 25 cyanobacterial species belonging to 16 genera were identified during this study. Most species showed wide range in their distribution among all surface and ground water sites. However, three species were recorded in all surface water sites, but not found in ground water sites. Two species were found only in all ground water sites. The results also showed that some species were restricted only to a certain site. Compared to the results of previous studies reported on freshwater cyanobacteria in Saudi Arabia, fifteen cyanobacterial species were identified as new records for Saudi Arabia during this study. Because of their ability to produce toxins, cyanobacteria should be monitored in surface and ground waters in Saudi Arabia in order to avoid their harmful effect on plant, animal and human health upon exposure to these waters.
\end{abstract}

Keyword: Cyanobacteria, surface water, ground water, Asir region, Saudi Arabia.

\section{Introduction}

Cyanobacterial microflora is still poorly known, particularly in tropical and arid regions such as Saudi Arabia. Diverse unknown morphotypes are found especially in geographically distinct tropical regions. Floristic papers describing and documenting the phenotype species from various regions are important ${ }^{[1]}$. Asir region contains the vast majority of permanent and semi-permanent water bodies in Saudi Arabia. This is because of the great and more frequent rainfall in this region. A number 
of studies on algal flora and cyanobacteria, of water bodies in different regions in Saudi Arabia, have been carried out by many authors. Abdelmohsen and Backhary ${ }^{[2]}$ studied the algal flora in Riyadah region. Three new records of cyanobacteria in Al-Qaseem region were reported by Aleem, et al. ${ }^{[3]}$. Khoja, et al. ${ }^{[4]}$ studied the freshwater algae in AlKharj and Al-Baha regions. Whitton, et al. ${ }^{[5]}$ surveyed the algal flora in some streams of Asir mountains. Al-Amoudi ${ }^{[6]}$ reported the algal vegetation in four streams in Makkah province. Khoja ${ }^{[7]}$ also studied the filamentous algae and cyanobacteria in the irrigation and drainage networks of Al-Hassa oases. Al-Homidan ${ }^{[8]}$ studied the algal vegetation of reservoirs in southwestern Saudi Arabia. Al-Homaidan and Arif ${ }^{[9]}$ recorded bloom-forming cyanobacterial species in semi-permanent rainfed pool at Al-Kharj. Recently, Jamel Al-layl ${ }^{[10]}$ and Jamel Al-layl et $a l .{ }^{[11]}$ studied the cyanobacteria in Fatima valley (Wadi Fatima) North east Makkah, Saudi Arabia.

In spite of the above studies on freshwater algae and cyanobacteria in Asir region, many water bodies are still not surveyed for the presence of algal flora and cyanobacteria in this region. Thus, the current study was carried out to predict cyanobacteria in surface water bodies and to study the occurrence of cyanobacteria in groundwater wells for the first time in Saudi Arabia. Thereby, this study would provide a contribution to the knowledge of cyanobacteria of Saudi Arabia.

\section{Materials and Methods}

\section{Study Sites}

All water bodies chosen for this study are located within Asir region. These water bodies were six surface water sites and six groundwater sites as shown in Fig. 1 and as follows:

\section{Surface Water Sites}

S1: Abha Dam lake, about $8 \mathrm{~km}$ northwest Abha downtown.

S2: Wadi Ghanum, located near Sarat Abidah city, and about $60 \mathrm{~km}$ southeast Abha city.

S3: Wadi Haly, in Muhayil Province, and about $85 \mathrm{~km}$ northwest Abha city.

S4: Al-Moqadda Dam, reservoir, at Al-Saudah area, and about $9 \mathrm{~km}$ northwest Abha city. 
S5: Wadi Gohan, located on Abha-Khamis Mushayt road, and about $12 \mathrm{~km}$ east Abha city.

S6: Wadi Ashran, located near Rjal Alma', and about $20 \mathrm{~km}$ southwest Abha city.

\section{Ground WaterWells}

G1: Groundwater well, located at Al-Saudah area, and about $23 \mathrm{~km}$ northwest Abha city.

G2: Groundwater well, located at Al-Qadah city, and about $64 \mathrm{~km}$ northeast Abha city.

G3: Groundwater well, located at Bishah city, and about $152 \mathrm{~km}$ northeast Abha city.

G4: Groundwater well, located at Ahad Rafidah city, and about 50 km east Abha city.

G5: Groundwater well, located in Khamis Mushayt city, and about $16 \mathrm{~km}$ east Abha city.

G6: Groundwater well, located in Tandaha city, and about $40 \mathrm{~km}$ east Abha city.

\section{Sampling}

Three water samples were collected in 500-ml polyethylene bottles from each site only once during the period from August to December, 2003. Water samples from surface water sites were collected by phytoplankton net $(25 \mu \mathrm{m}$, mesh size $)$ at $0.5 \mathrm{~m}$ depth, while water samples from groundwater wells were taken by lowering the polyethylene bottles to about $0.5 \mathrm{~m}$ beneath the water level. The samples of each site were mixed together and divided into two parts; one of them was preserved in Lugol's solution (1\% final concentration), while the other part was enriched with BG 11 medium ${ }^{[12]}$ and kept under continuous light supported by fluorescent lamps $\left(25 \mu \mathrm{mol} \mathrm{m}^{-2} \mathrm{~s}^{-1}\right)$ at room temperature $\left(25 \pm 2{ }^{\circ} \mathrm{C}\right)$. Cyanobacterial species were identified in preserved samples and enriched cultures according to Geitler [13]; Prescott ${ }^{[14]}$; John et al. ${ }^{[15]}$, and the floristic papers of Komarek and Kling ${ }^{[16]}$; Sant' Anna and Azevedo ${ }^{[17]}$ and Saker et al. ${ }^{[18]}$. The new records of cyanobacteria were photographed with a Camera connected to an Olympus research microscope.

\section{Physico-Chemical Analysis}

Physical parameters (temperature, $\mathrm{pH}$, conductivity) were measured using thermometer, $\mathrm{pH}$-meter, and conductivity meter, respectively. 
Chemical analyses were carried out according to Standard methods ${ }^{[19]}$, briefly, nitrate by Na-salcylate method, ammonia by Nessler's reagent, soluble reactive phosphate by ascorbic acid method.

\section{Statistical Analysis}

Differences in environmental variables among the studied sites of surface and ground waters were examined by one-way ANOVA $(\mathrm{P}=0.05)$. Spearman rank correlation coefficients were also used to measure the degree of association between the physical and chemical properties, and the total number of species.

\section{Results}

The physical and chemical properties differed significantly between surface and ground waters $(\mathrm{p}<0.05)$. The $\mathrm{pH}$ of all surface and ground waters sites surveyed during the present study was slightly alkaline (7.78.2). Nitrate and phosphate concentrations are much greater in surface waters than in ground waters (Table 1). On the other hand, conductivity, $\mathrm{NO}_{3}^{-}, \mathrm{NH}_{4}^{+}, \mathrm{PO}_{4}^{-3}$ concentrations showed a great variation among surface water sites $(\mathrm{P}<0.05)$, but no significant difference in temperature or $\mathrm{pH}$ was observed among these sites $(\mathrm{P}>-0.05)$. All these variables did not differ significantly among groundwater sites $(\mathrm{P}>0.05)$.

As shown in Table (2), a total of 25 cyanobacterial species were identified in the studied sites of surface and ground water bodies. Most species showed wide range in their distribution among all sites of study. However, three species, namely, Aphanothece clatharta, Oscillatoria limnetica, and Pseudanabaena catenata, were recorded in all surface water sites, and not found in groundwater sites. Whereas, two species, namely, Chroococcus minutus and Pannus spumosus, were recorded in all ground water sites only. On the other hand, the total number of species correlated positively with temperature and conductivity $(\mathrm{r}=0.4$, 0.55 , respectively), and negatively with $\mathrm{NO}_{3}{ }^{-}$and $\mathrm{PO}_{4}{ }^{-3}$ concentrations $(\mathrm{r}=-0.3,-0.33$, respectively). Whereas, the total number of species in surface and ground waters did not correlate with either $\mathrm{pH}$ or $\mathrm{NH}_{4}^{+}$ concentrations $(\mathrm{r}<0.1)$.

The results also showed that some species were restricted only to a certain site. For instance, Cylindropsermopsis raciborskii and Gomphosphaeria aponina were recorded only in S1 site (Abha Dam 
lake), Microcystis aeruginosa in S2 site (Wadi Ghanam), and Stigonema hormoids in G4 site. Compared to the results of previous studies reported on freshwater cyanobacetria in Saudi Arabia, fifteen cyanobacterial species were identified as new records to Saudi Arabia in this study. Descriptions and photographs of newly reported species are given below.

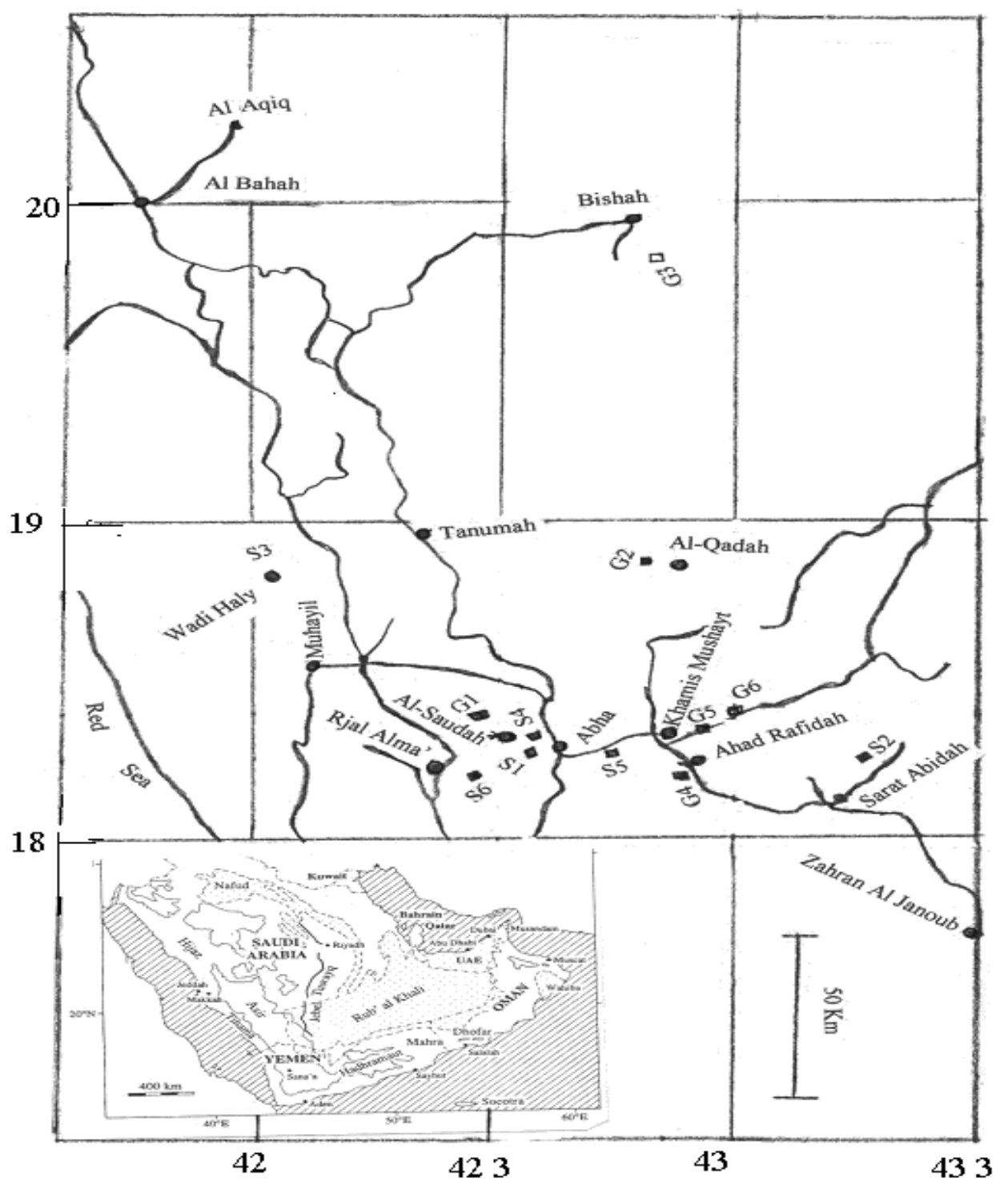

Fig. 1. Map showing location of the studied sites of surface and groundwater bodies in Asir region (ロ Site, $\bullet$ City). 


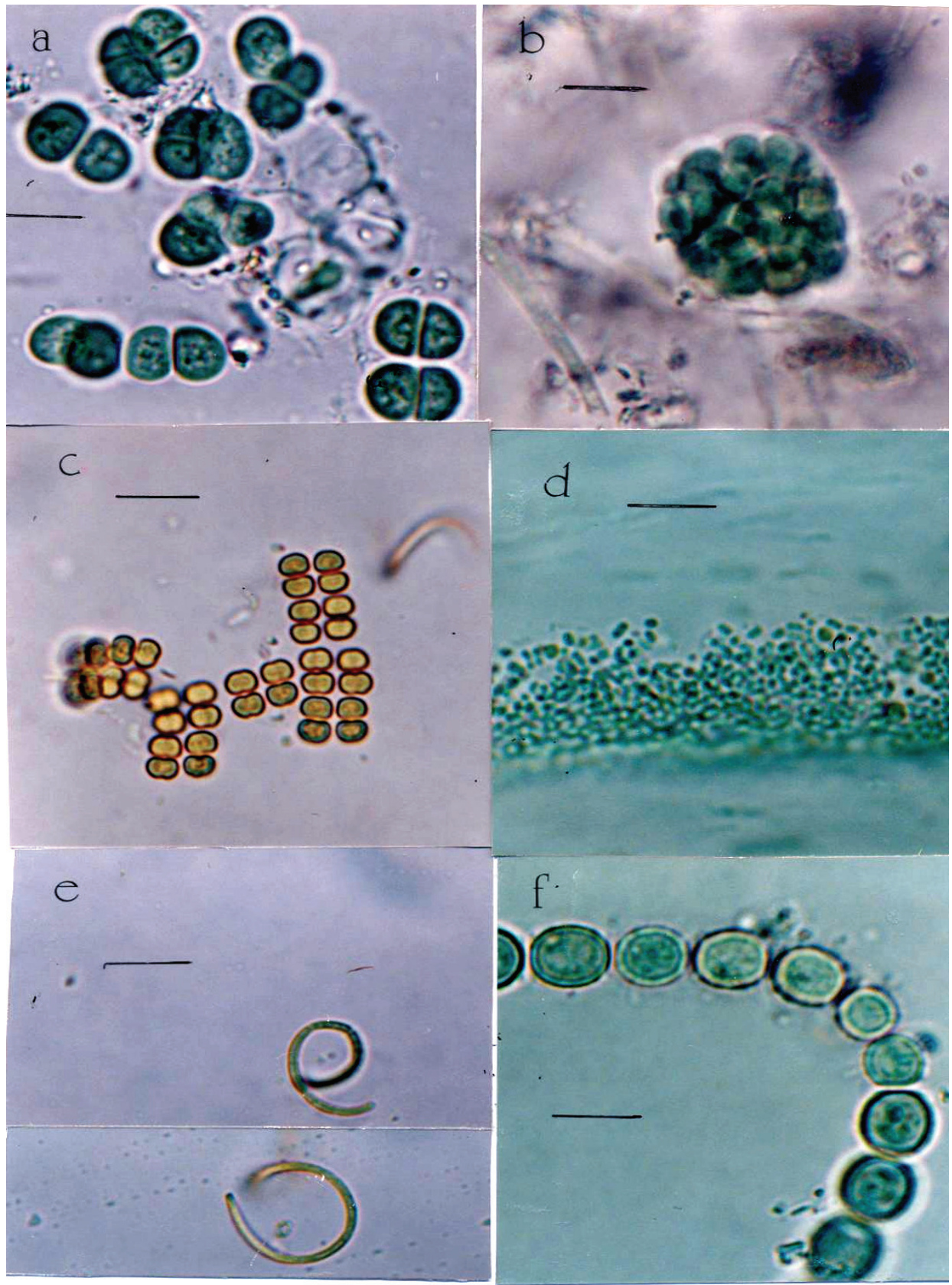

Fig. 2. Light microscope photographs of new records of Cyanobacteria to Saudi Arabia: a. Chroococcus minutus, b. Hydrococcus rivularis, c. Merismopedia punctata, d. Pannus spumosus, e. Cylindrospermopsis raciborskii, f. Nostoc sphaericum. (each scale bar $=10 \mu \mathrm{m}$; magnification $=1000 \mathrm{x})$. 


\section{Order: Chroococcales}

\section{Chroococcus Minutus (kutzing) Nageli (Fig. 2-a).}

Basionym: Protococcus minutus Kutzing 1842.

Colony small, 2-4 cells, cells solitary, spherical or ovoid shape, 3.9$7.8 \mu \mathrm{m}$ in diameter, with a wide homogenous sheath. The species was recorded in all groundwater sites (G1-G6).

\section{Hydrococcus Rivularis kutzing (Fig. 2-b).}

Synonym: Oncobyrsa rivularis (Kutzing) Meneghini 1846.

Colony hemispherical, about $26 \mu \mathrm{m}$ in diameter. Margins of the colony with short radially arranged row of cells. Cells spherical, broadly ellipsoidal or more elongate and curved at the outer end of a radial row. Cell, 3.3-5.8 x 4.7-7.2 $\mu \mathrm{m}$. The species was identified in surface water (S1) and ground water well (G1), respectively.

\section{Merismopedia Punctata Meyen (Fig. 2-c).}

Colony up to 64 cells arranged loosely. Cells, ellipsoidal or (after division) hemispherical, 3.3-5.2 $\mu \mathrm{m}$ in diameter. This species is scarcely distinguishable from M. glauca, but the cells of this species tend to be small. The species was recorded in both surface water (S3 and S4) and groundwater (G1, G2 and G5) sites, respectively.

\section{Pannus spumosus Hickel 1991 (Fig. 2-d).}

Colony microscopic irregularly spherical. Cells ellipsoidal, 1.3-2.6 $\mu \mathrm{m}$ in diameter, with individual indistinct mucilage layer, without gas vacuoles. The species was identified in all sites of groundwater.

\section{Order: Nostocales}

5. Cylindrospermopsis raciborskii (Taylor) Komarek 1984 (Fig. 2-e).

Synonym: Anabaenopsis raciborskii Woloszynska 1912

Filaments 35-39 $\mu \mathrm{m}$ long, coiled, cells cylindrical, 1.2-2 $\mu \mathrm{m}$ width, 3-4.5 $\mu \mathrm{m}$ long. This species is confused with $C$. philippinensis, but the latter is characterized by strongly spiral trichomes and wider cells. The species was identified only in one surface site (S1).

\section{Nostoc sphaericum (Vaucher 1803) Bornet et Falah. (Fig. 2-f).}

Filaments thickly entangled. Trichomes mostly lacking individual sheath. Cells barrel-shaped or rounded, 6- $6.8 \mu \mathrm{m}$ in width, 7- $10.5 \mu \mathrm{m}$ long. Akinete ellipsoidal with smooth walls. The species was identified in three sites of surface waters (S1, S3 and S5) and one site of groundwater (G1). 


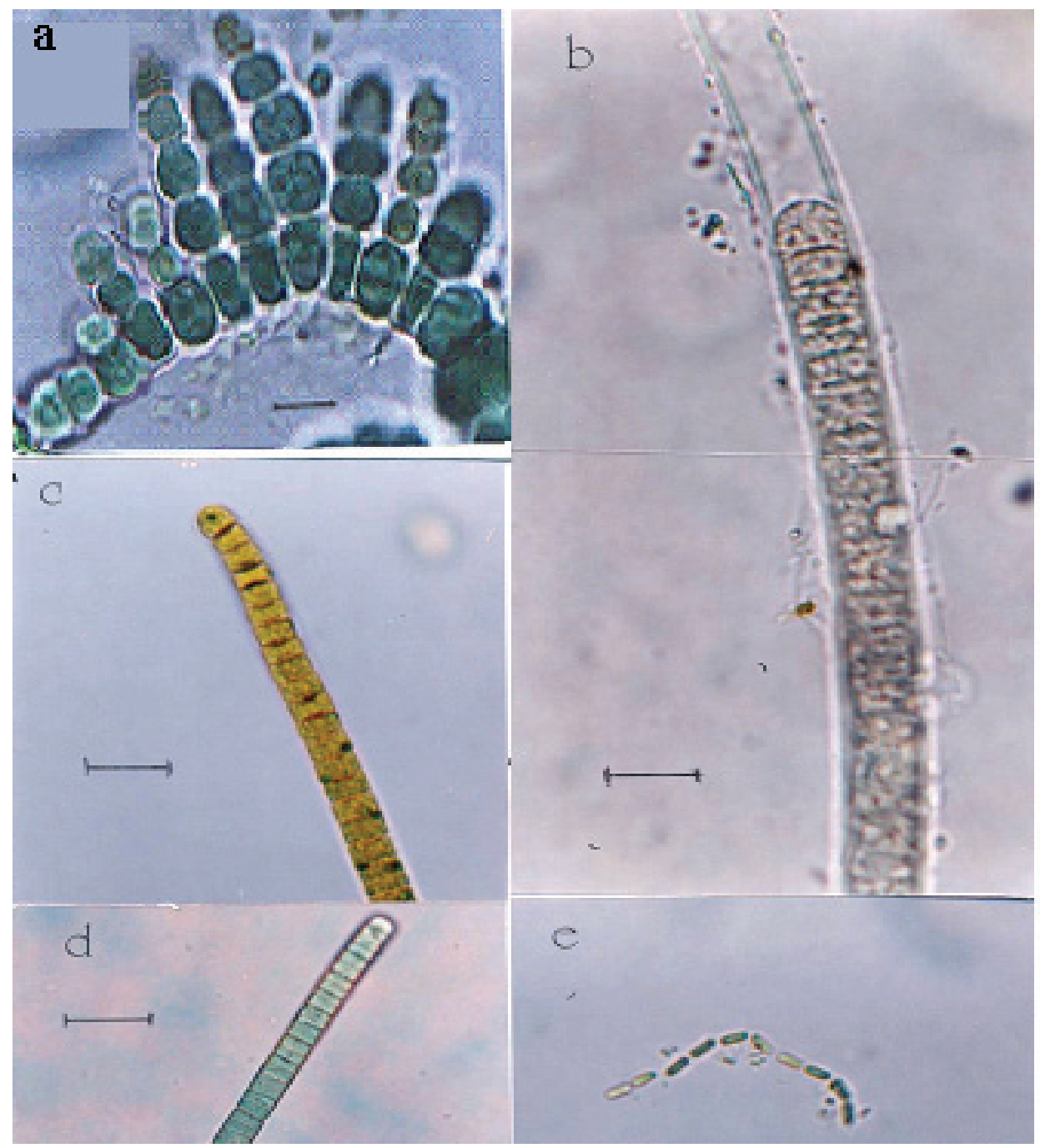

Fig. 3: Light microscope photographs of new records of Cyanobacteria to Saudi Arabia:

a. Stigonema hormiods, b. Lyngbya martensiana, c. Oscillatoria chalybea,

d. Oscillatoria tenuis, e. Phormidium dictyothallum (each scale bar $=10 \mu \mathrm{m}$; magnification $=1000 x$ ).

\section{Order: Stigonematales}

7. Stigonema hormiods (Kutzing) Borent et Falah. (Fig. 3-a).

Filaments form blackish- brown thallus. Filaments $6.8-10 \mu \mathrm{m}$ wide, irregularly branched, with sub-erect, or sometimes curved branches. Cells 
sphaerical, 3.2-5.2 $\mu \mathrm{m}$ wide, arranged in one row. Heterocysts, present in both main and branch filaments. Sheath colorless and thick. The species was identified only in one site of groundwater (G4).

\section{Order: Oscillatoriales}

\section{Lyngbya martensiana (meneghini) Gomont (Fig. 3-b).}

Synonym: Porphyrosiphon martensians (Gomont) Anagostids et Komarek 1988

Filaments long, blue-green 10-13 $\mu \mathrm{m}$ wide. Trichomes not attenuated, not constricted. Cells 7.8- $11.7 \mu \mathrm{m}$ wide, 2.6-3.9 $\mu \mathrm{m}$ long, cross walls granulated, apical cell rounded without calyptra. Sheath thick and homogeneous. The species was recorded in two sites of surface water (S2 \& S5) and two sites of groundwater (G3 \& G6).

\section{Oscillatoria chalybea Mertens ex Gomont var. minor Kainat (Fig. 3-c).}

Trichomes entangled, curved at the apex, attenuated and constricted. Cells 2.6- $3.4 \mu \mathrm{m}$ long, 5.2- $6.8 \mu \mathrm{m}$ wide. Cell contents, blue-green, granulated, cross walls generally not granulated, apical cell rounded, or truncate, without thickned outer membrane. The species was identified in one site only of surface water (S5), and three sites of groundwater (G3, G5 \& G6).

\section{Oscillatoria tenuis (Agardh) Gomont (Fig. 3-d).}

Synonym: Phormidium tenue (Gomont) Anagnostids et Komarek 1988.

Trichomes, solitary, straight or slightly curved at the apex, not attenuated, constricted 3.2-4.5 $\mu \mathrm{m}$ wide, 2- $2.6 \mu \mathrm{m}$ long. Cross walls granulated, apical cell, hemisphaerical with thickened outer membrane. The species was investigated in two sites only of surface water (S4 \& S5).

\section{Phormidium dictyothallum (Skuja) Sant' Anna et Azevedo 1995} (Fig. 3-e).

Filaments loosely entangled, flexuous, sheath hyaline, inconspicuous. Trichomes, not attenuated, slightly constricted. Cells 3.4$5 \mu \mathrm{m}$ long, 1.4-2.6 $\mu \mathrm{m}$ wide, up to 2.3 times longer than wide. Cross walls not granulated, apical cell conical, without thickened outer membrane. The species was identified in one site of surface water (S4) and two sites of groundwater (G2 \& G5). 


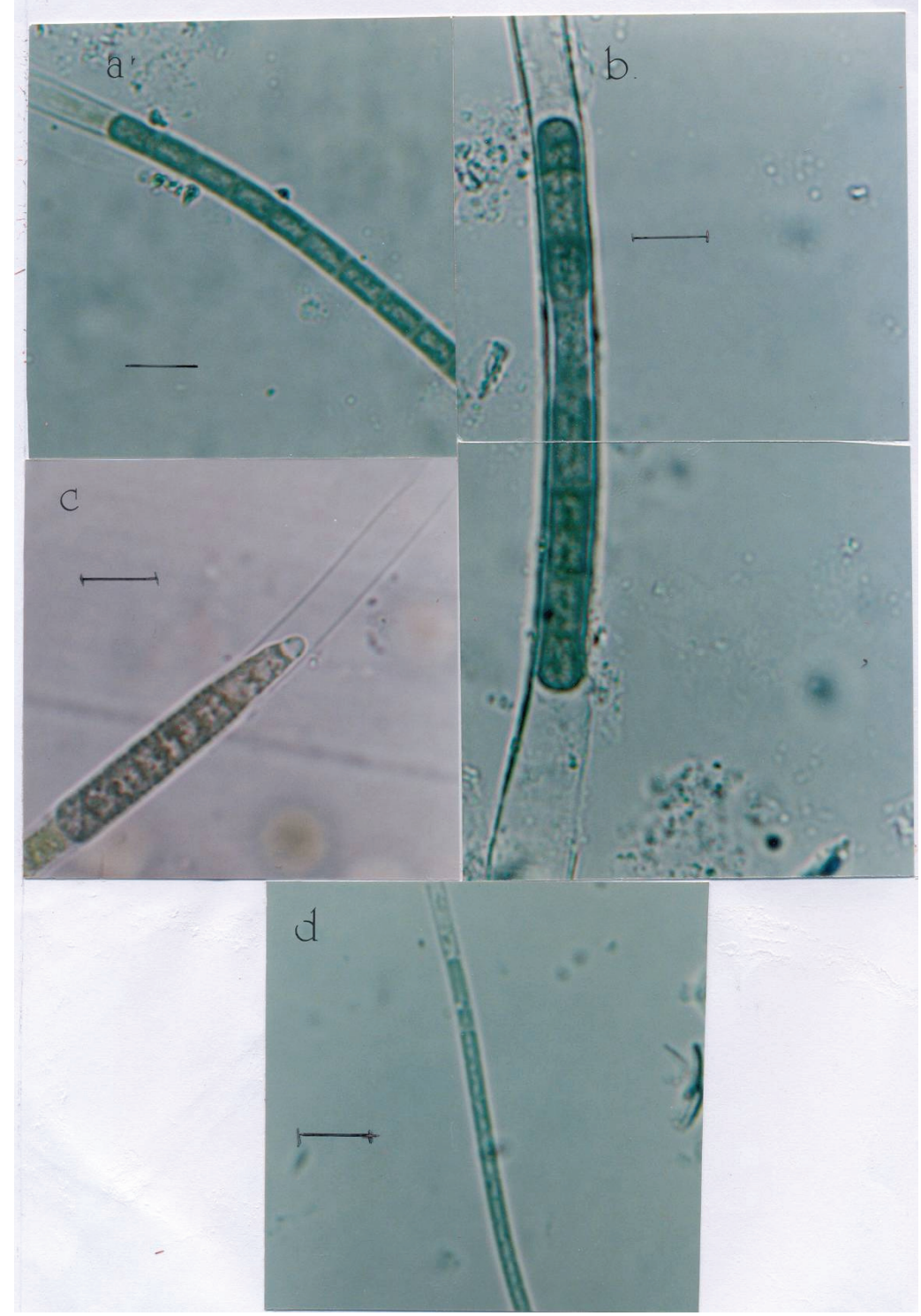

Fig. 4. Light microscope photographs of new records of Cyanobacteria to Saudi Arabia:

a. Phormidium luridium, b. Phormidium retzii, c. Phormidium subfusicum, d. Phormidium tenue (each scale bar $=10 \mu \mathrm{m}$; magnification $=1000 \mathrm{x}$ ).

12. Phormidium luridium (Kutzing) Gomont (Fig. 4-a). Synonym: Leptolyngbya lurida (Gomont) Angnostids et Komarek 1988. 
Trichomes, flexibles, not attenuated or curved towards the apex. Cells longer than wide, 5-6.8 $\mu \mathrm{m}$ long, 2.5-3.4 $\mu \mathrm{m}$ wide. Cross walls, slightly narrowed, not granulated. Sheath, thin, soft. End cell, rounded, without calyptra. The species was identified in two sites of surface water only (S3 \& S5).

\section{Phormidium retzii (Agardh) Gomont (Fig. 4-b).}

Filaments, straight, sheath conspicuous. Trichomes, not attenuated, not constricted. Cells 5-6 $\mu \mathrm{m}$ in wide, 4.2-5 $\mu \mathrm{m}$ long. Cross walls, slightly narrowed, not granulated. Apical cell, slightly rounded without thickened outer membrane. The species was identified in one site of surface water (S3) and two sites of groundwater (G1 \& G6).

\section{Phormidium subfusicum (Kutzing) Gomont (Fig. 4-c).}

Filaments, loosely entangled, flexuous. Sheath diffluent forming a layer of gelatinous matrix. Trichomes, attenuated. Cells, 5.9- $7.5 \mu \mathrm{m}$ wide, 2.6-4.2 $\mu \mathrm{m}$ long, up to two times broader than long. Apical cell, conical with rounded calyptra. The species was identified in one site of surface water (S5) and two sites of groundwater (G2 \& G6).

\section{Phormidium tenue (Meneghini) Gomont (Fig. 4-d).} 1988.

Synonym: Leptolyngbya tenuis (Gomont) Angnostids et Komarek

Trichomes, straight. Cells, 2- $2.6 \mu \mathrm{m}$ wide, 3.4-4.2 $\mu \mathrm{m}$ long. Cross walls narrowed, not granulated. Apical cell, conical without calyptra. Sheath, thin and gelatinous. The species was identified in one site of surface water (S6) and one site of groundwater (G2).

\section{Discussion}

Cyanobacteria have been reported to have some relevance to agriculture and/ or soil stabilization or reclamation, albeit clearly some are more tangibly related than others ${ }^{[20]}$. Thus, global biodiversity and high priority investigations should include documentation of species and ecosystem diversity as well as organismal survival mechanism.

Water and dissolved minerals are ubiquitous and essential resources for all life forms. Limitation or excess for one or both of these two factors could have an effect on algae and cyanobacteria ${ }^{[21,22,23]}$. Since Asir region is considered as a semi-arid region in Saudi Arabia, it could contain certain species of cyanobacteria which sustain under these conditions. So, it is not surprising to get such a low number of cyanobacterial species in this region during this study when compared to 
the number recorded elsewhere in other regions. The results of present study also showed that the total number of species in surface and ground waters correlated positively with temperature and conductivity. This finding supports the hypothesis that cyanobacteria grow best at high temperatures ${ }^{[24]}$. The negative correlation between the total number of cyanobacterial species in surface and ground waters and $\mathrm{NO}_{3}{ }^{-}$and $\mathrm{PO}_{4}{ }^{-3}$ concentrations, agrees with the finding of Yusoff and McNabb [25] reporting that high concentrations of nitrogen and phosphorus make the environment less suitable for the dominance of cyanobacteria. Otherwise, cyanobacteria seem to be dominant at low ratio of $\mathrm{N}: \mathrm{P}$, where some species are capable of synthesizing their own nitrogen through nitrogen fixation [26]. Some of the previous studies recorded high number of freshwater cyanobacteria in Saudi Arabia, while other studies reported low number of species. Whitton et al. ${ }^{[5]}$ recorded 38 species of cyanobacteria in streams in Asir mountains. Khoja ${ }^{[7]}$ identified 40 cyanobacterial species in irrigation and drainage network of Al-Hassa Oases. Al-Homaidan ${ }^{[8]}$ investigated 17 cyanobacterial species in reservoirs in southwestern Saudi Arabia. Al-Homaidan and Arif [9] recorded 14 species of bloom-forming cyanobacteria in semi-permanent rain-fed pool at Al-Kharj.

Table 2. List of cyanobacterial species identified in surface and groundwater sites in Asir region during the present study.

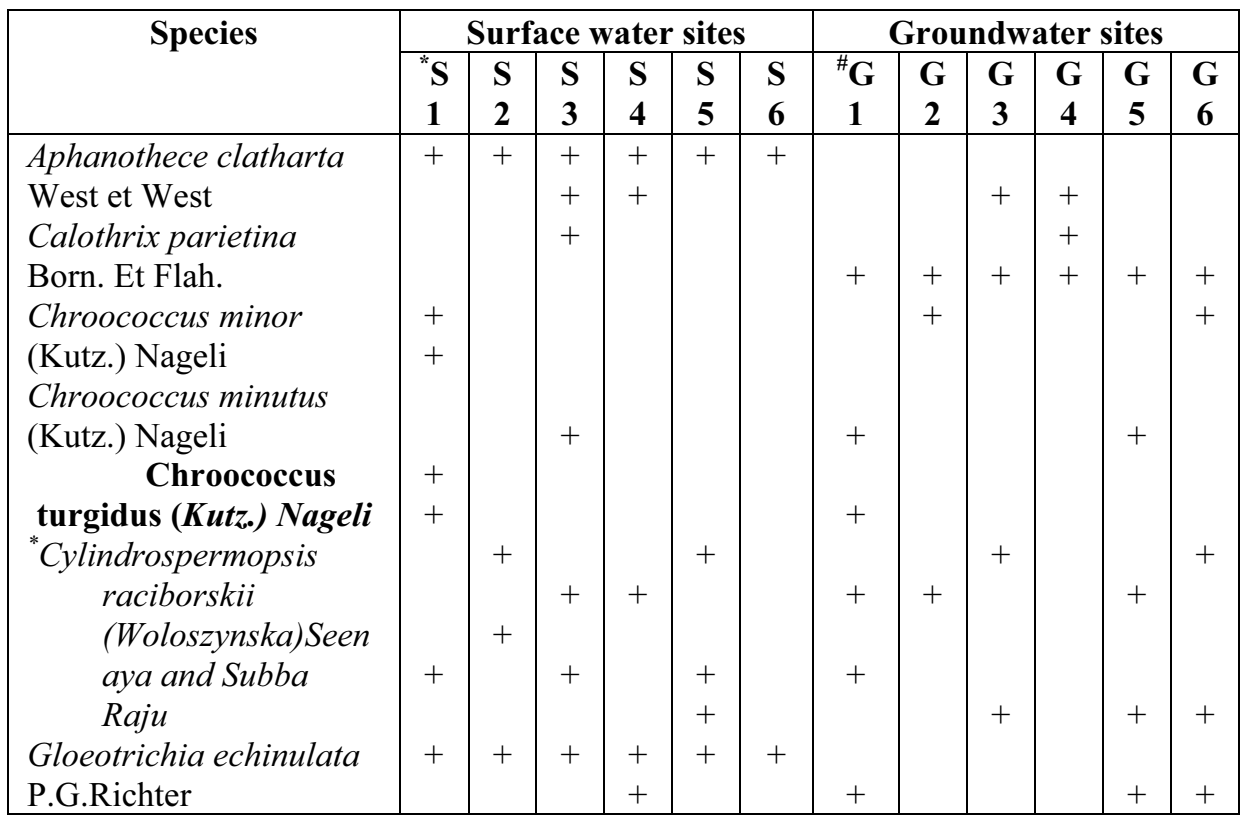




\begin{tabular}{|c|c|c|c|c|c|c|c|c|c|c|c|c|}
\hline $\begin{array}{l}\text { Gomphosphaeria } \\
\text { aponina Kutz. } \\
\text { Hydrococcus rivularis } \\
\text { Kutz. } \\
\text { Lyngbya martensiana } \\
\text { Gomont } \\
\text { Merismopedia punctata } \\
\text { Meyen } \\
\text { *Microcystis aeruginosa } \\
\text { Kutz.. } \\
\text { Nostoc sphaericum Born } \\
\text { et Flah. } \\
\text { Oscillatoria chalybea } \\
\text { var. minor Kain. } \\
\text { Oscillatoria limnetica } \\
\text { Lemm. } \\
\text { Oscillatoria limosa } \\
\text { Gomont } \\
\text { * Oscillatoria } \\
\text { tenuisGomont } \\
\text { Pannus spumosus Hickel } \\
\text { Phormidium } \\
\text { dictyothallum Skuja } \\
\text { Phormidium luridium } \\
\text { Gomont } \\
\text { Phormidium retzii } \\
\text { Gomont } \\
\text { Phormidium subfusicum } \\
\text { Gomont } \\
\text { Phormidium tenue } \\
\text { Gomont } \\
\text { Pseudoanabaena } \\
\text { catenata Lauterborn } \\
\text { Stigonema hormoides } \\
\text { Born et Flah. } \\
\text { Total number of species }\end{array}$ & 8 & 5 & $\begin{array}{l}1 \\
0\end{array}$ & $\begin{array}{l}+ \\
+ \\
+\end{array}$ & + & $\begin{array}{l}+ \\
+\end{array}$ & + & $\begin{array}{l}+ \\
+\end{array}$ & + & $\begin{array}{l}+ \\
5\end{array}$ & $\begin{array}{l}+ \\
+\end{array}$ & $\begin{array}{l}+ \\
+\end{array}$ \\
\hline
\end{tabular}

$*=$ Toxin producing species.

Cyanobacteria showed some similarities in the species composition between surface and groundwater sites during this study. This may be explained by the hypothesis that there are no barriers for algae to transport by wind and water-wind flows, which move them over great distances and as a result, they can settle on various substrates, reservoirs and groundwater wells ${ }^{[27]}$. To a lesser extent, the algae are delivered from water reservoirs by strong wind, which could be able to blow off 
liquid drops from wave peaks ${ }^{[28,29]}$. Therefore, the presence of some species of cyanobacteria in both surface and ground waters might occur by wind from the same source "soil", or occur by transfer of these species by water-wind flows from surface water to groundwater wells. In this respect, Dubovik ${ }^{[29]}$, demonstrated the carrying of some species of cyanobacteria with rainwater flows to rainwater puddles. This may reflect the capability of these species to populate any place, as tree trunks, granite, marble and buildings. Consequently, these species could cause a destruction of stone quays and old building ${ }^{[30,31]}$. So, this should be considered for buildings protection against the corrosive effect of these species. Also, the presence of cyanobacteria in surface and ground waters in Asir region indicates the high trophic status of these water bodies ${ }^{[32,33]}$.

\section{Conclusion}

During this study, fifteen cyanobacterial species were reported as new records for Saudi Arabia. The present study also found that species composition of cyanobacteria showed some similarity in both semipermanent bodies and groundwater wells in Asir region. Since most of cyanobacterial species are well known to produce toxins ${ }^{[34]}$, the presence of cyanobacteria in surface and ground waters in Asir region, should be taken into account during the management of these water bodies in order to avoid the harmful effect of cyanobacteria on plant and animal health upon consuming such waters.

\section{Acknowledgment}

The authors thank and appreciate Dr. Hussein Al- Wadai and Mr. Mohamed Aseery, Department of Biological Sciences, Faculty of Sciences, King Khalid University, for guidance of sample collection and photographing of algal species.

\section{References}

[1] Komarek, J. and Komarkova-Legnerova, J., Contribution to the knowledge of planktic cyanoprokaryotes from central Mexico, Preslia, Praha., 74: 207-233 (2002).

[2] Abdelmohsen, A.F. and Backhary, I. A., A Study on distribution and periodicity of freshwater algae in Riyadah area as related to environment, Bulletin of Faculty of Science, Riyadah University, 1: 2-56 (1969).

[3] Aleem, A.A., Khafaje, A.K. and Al-Bassam, B.A., An algal community from hot springs at Al-Qaseem, Saudi Arabia. Bulletin of Faculty of Science, King Abdulaziz University, 6:73-75 (1982). 
[4] Khoja, T.M., Mady, M.A. and Hussain, M.I., Freshwater algae from Saudi Arabia. I. Bluegreen algae (Cyanobacteria), Chorophyta and Bacillariophyta, Journal of College of Science, King Saud University, 15: 113- 125 (1984).

[5] Whitton, B.A., Khoja, T.M. and Arif, I.A., Water chemistry and algal vegetation of streams in the Asir Mountains, Saudi Arabia, Hydrobiologia, 133: 97-106 (1986).

[6] Al-Amoudi, O.A., Preliminary studies on water chemistry and algal vegetation of freshwater streams in Makkah Province, Saudi Arabia, Journal of the University of Kuwait (Science), 15: 97-101 (1988).

[7] Khoja, T.M. Water composition and filamentous algae in the irrigation and drainage networks of Al-Hassa Oases, Saudi Arabia, Cryptogamic Botany, 4: 1-7 (1993).

[8] Al-Homaidan, A.A., Water chemistry and algal vegetation of reservoirs in southwestern Saudi Arabia, Journal of the University of Kuwait (Science), 1: 51-60 (1994).

[9] Al-Homaidan, A. and Arif, I.A., Ecology and bloom-forming algae of a semi-permanent rain-fed pool at Al-Kharj, Saudi Arabia, J. Arid Environ., 38: 15-25 (1998).

[10] Jamel Al-Layl, K.M., Phylogenetic Analysis of the Toxic Nanoplanktonic Cyanobacterium Synechocystis sp. Isolated from Makkah, Saudi Arabia, Umm Al-Qura Univ. J. Sci. Med. Eng., 14:1-7 (2002).

[11] Jamel Al-layl, K.M. Liver Injury Induced by the Hepatotoxicity of the Nanoplanktonic Cyanobacterium Synechocystis aquatilis Isolated from Makkah, Saudi Arabia, Umm AlQura Univ. J. Sci. Med. Eng., 15: 1-12 (2003).

[12] Stanier, R.Y., Kunisawa, R., Mandel, M. and Cohen-Bazire, G., Purification and properties of unicellular blue-green algae (order Chroociccales), Bacteriological Review, 35: 171-205 (1971).

[13] Geitler, L., Cyanophycea, In: Rabenhorts's Kryptogamenflora von Deutschland, Osterreich und Schweiz, Akad. Verl., Leipzing, 14: 1-1196 (1932).

[14] Prescott, G.W., Algae of the Western Great lakes Area with an Illustrated Key to the Genera of Desmids and Freshwater Diatoms, Otto Koeltz Science Publishers (1982).

[15] John, D.M., Whitton B.A. and Brook, A.J., The freshwater algal flora of the British Isles: An identification guide to freshwater and terrestrial algae, $1^{\mathrm{st}}$ ed., Cambridge Univ. Press (2002).

[16] Komarek, J. and Kling, H., Variation in six planktic cyanophyte genera in Lake Viktoria (East Africa). Archives fur Hydrobiologie/ Algological Studies, 61: 24-45 (1991).

[17] Sant' Anna, L. and Azevedo, M.T.D., Oscillatoriaceae (Cyanophyceae) from Sao Paulo State, Brazil. Nova Hedwigia 60: 19-58 (1995).

[18] Saker, M. L., Neilan, B.A. and Griffiths, D.J., Two morphological forms of Cylindrospermopsis raciborskii (Cyanobacteria) isolated from Solomon Dam, Plam Island, Queensland, J. Phycol., 35: 599-606 (1999).

[19] APHA., Standard Methods for the Examination of Water and Wastewater, 19th ed. American Public Health Association, Washington (1995).

[20] Henley, W.J., Algae and cyanobacteria under desiccation and ionic stress, Nova Hedwigia, Beiheft, 123: 443-452 (2001).

[21] Bell, R.A., Cryptoendolithic algae of hot semiarid lands and desert, J. Phycol., 29: 133-139 (1993).

[22] Johansen, J. R., Cryptogamic crusts of semiarid and arid land of North America, J. Phycol., 29:140-147 (1993).

[23] Fletchner, V.R., Enigmatic desert soil algae, In: Seckbach, J. (Ed.): Enigmatic microorganisms and life in extreme environments, Kluwer, Dordrecht pp: 231-241 (1999).

[24] Ward, D.M., Ferris, M.J., Nold, S.C. and Bateson, M.M., A natural view of microbial biodiversity within hot spring cyanobacterial mat communities, Microbiological and Molecular Biology Review, 62:1353-1370 (1998). 
[25] Yusoff, F.M. and McNabb, C.D., The effects of phosphorus and nitrogen on phytoplankton dominance in tropical fish ponds, Aquaculture Research, 28: 591-597 (1997).

[26] Smith, V.H., Low nitrogen to phosphorus ratios favor dominance by blue-green algae in lake phytoplankton, Science, 221: 669-671 (1983).

[27] Dubovik, I.E., Algae in Eroded Soils and Algological Estimation of Soil Protective Measures, Beshkir University Press, Ufa. (Rus.) (1995).

[28] Vlodavets, V.V., Algae in atmospheric air, Priroda, 2: 85-68 (Rus.) (1960).

[29] Dubovik, I.E., Migration of aerophytic algae and their colonization on different substrata, International Journal of Algae, 4(2): 48-55 (2002).

[30] Petushkova, Y.P. and Keptiayeva, T.F., Study of green algae and cyanobacteria causing damage of architectural monuments, Ixv. An USSR. Biol. Ser., 2: 306-308. (Rus.) (1984).

[31] Andreoli, C. and Rascio, N., Microalgal growing on different substrates used in Venetian buildings, G. Bot. Ital., 120: $72-73$ (1986).

[32] Rawson, D.S., Algal indictors of trophic lakes types, Limnol. Oceanogr., 1: 18-25 (1956).

[33] Rosenström, U. and Lepistö, R., Phytoplankton indicator species of different types of boreal lakes, Algological Studies, 82: 131-140 (1996).

[34] Carmichael, W.W., Health effects of toxin producing cyanobacteria: the cyano HABs, Human Ecol. Risk Assess, 7: 1393-1407 (2001). 


\section{السيانوبكتريا في المياه السطحية و الجوفية في منطقة عسير و أنو اع جديدة بالنسبة للمملكة العربية السعودية}

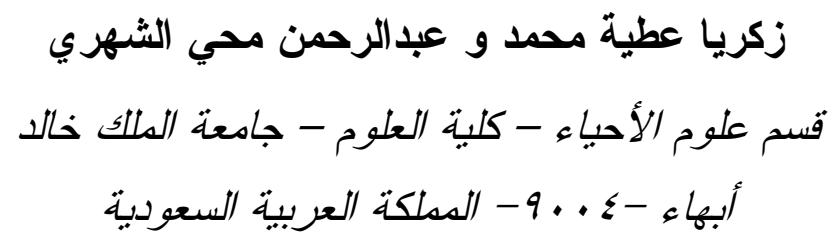

المستخلص. تم حصر أنواع السيانوبكتريا الموجودة في ستة مواقع للمياه السطحية ( الوديان، وخز انات السدود) و ستة أبار مياه جوفية

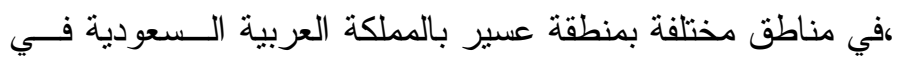

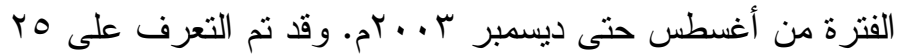

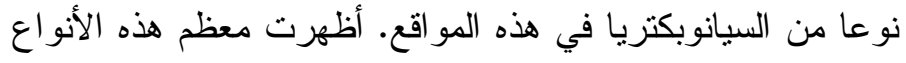

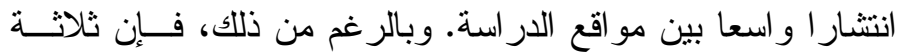

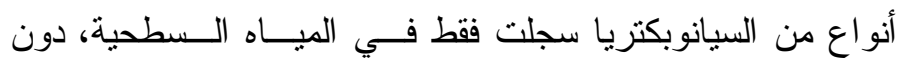
الجوفية، و نوعان سجلا فقط في المياه الجوفية دون السطحية. كما

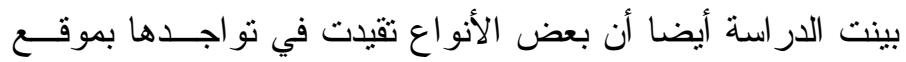

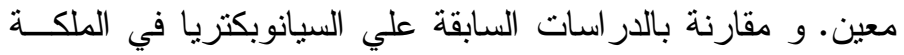

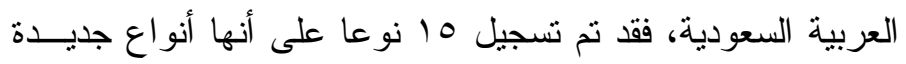
بالنسبة لسيانوبكتريا المملكة خلال هذه الدر اسة. 